\title{
An Exploratory Study of Personification and Hyperbole in Selected Siswati Poetry
}

\author{
Dr Jozi Joseph Thwala \\ University of Mpumalanga Private Bag X11283 Mbombela South Africa 1200
}

Type of Work: Peer-Reviewed

DOl: http://dx.doi.org/10.21013/jems.v15.n5.p1

\section{How to cite this paper:}

Thwala, J.J. (2019). An Exploratory Study of Personification and Hyperbole in Selected Siswati Poetry. IRA International Journal of Education and Multidisciplinary Studies (ISSN 2455-2526), 15(5), 160-166. doi: http://dx.doi.org/10.21013/jems.v15.n5.p1

(c) Institute of Research Advances.

This work is licensed under a Creative Commons Attribution-Non Commercial 4.0 International License subject to a proper citation to the publication source of the work.

Disclaimer: The scholarly papers as reviewed and published by the Institute of Research Advances (IRA) are the views and opinions of their respective authors and are not the views or opinions of the IRA. The IRA disclaims of any harm or loss caused due to the published content to any party.

Institute of Research Advances is an institutional publisher member of Publishers International Linking Association Inc. (PILA-CrossRef), USA. The institute is an institutional signatory to the Budapest Open Access Initiative. Hungary advocating the open-access of scientific and scholarly knowledge. The Institute is a registered content provider under Open Access Initiative Protocol for Metadata Harvesting (OAI-PMH).

The journal is indexed \& included in WorldCat Discovery Service (USA), CrossRef Metadata Search (USA), WorldCat (USA), OCLC (USA), Open J-Gate (India), EZB (Germany) Scilit (Switzerland), Airiti (China), Bielefeld Academic Search Engine (BASE) of Bielefeld University, Germany, PKP Index of Simon Fraser University, Canada. 


\begin{abstract}
This is an exploratory study of two selected figure of speech: personification and hyperbole. They are, however, selected as key rhetoric devices that depict the poetic language and style. They are central figures of speech that are significant in the poetic sentences and semantic content. This study is guided by Formalism approach based on poetic sounds, syntactic and semantic construction. They are used to achieve a special meaning or effect in all modes of discourse. They are integral to the functioning of language in a connotative manner. These figures of speech extend the meaning of words or phrases beyond the normal way as a result of mental association. Their functions are for the emphasis ironic effect and animation. The formalist approach is adopted because it helps the readers to analyse the writer's technical prowess and craft skills. It believes that in any work of art such as poetry, the poetic sometimes deliberately defamiliarizes the raw material and objects of familiar actions and words that he uses to build up his poem.
\end{abstract}

Keywords: Ironic effect, mental association, modes of discourse, technical prowess, rhetorical devices.

\title{
Introduction
}

Cuddon (1980:322-323) stresses the fact that the terms image and imagery have many meanings. Imagery is a broad term that covers the use of language to stand for objects, feelings and sensory or extrasensory experience. $\mathrm{He}$ indicates that an image may be visual, tactile, auditory and gustatory. He further distinguishes between literal, perceptual and conceptual types of imagery. In regard to the first type, no figurative meaning is involved, while the latter types are characterised by a figurative meaning.

Other scholars hold the opinion that language utterances can be identified as an image if figurative meaning is involved. Cohen (1973:51) says the term imagery is significant to the study of poetic style, images and figures of speech. He regards figure of speech as worth considering in terms of poetic style, namely allusion, simile, personification, metaphor and symbol.

Van Staden (1980:28-48) illustrates several forms of the metaphor (personification and iron) which are traditional regarded by some scholars as forms of imagery. The study intends to evaluate different viewpoints, but to identify poetic phenomena which are traditionally regarded as imagery or even figures of speech, and to investigate their specific functions of the context of Swati poetry.

\section{Research Approach and Theoretical Underpinning}

The theory developed as a reaction to the emphasis in Russian criticism, synthesis and analysis on the content and social significance of the literature (Abrams 1988:235)

The term formalism was initially used by the contestants of this approach. This term stems from the assertion that this approach puts on the patterns of sound, words, and literary devices more than the subject matters and social values of poetry. It emphasizes sound combinations that should be evaluated in terms of its phonic elements. In formalism, a poem violates the linguistics rules of the language by foregrounding its sounds namely: alliteration, assonance, consonants, rhyme, and other sounds devices.

By foregrounding its phonic elements, poetry creates music and the poetic devices have an effect of estranging pronunciation. The second principle of poetry lies in the syntactic structures. Poetry should thus be analysed and assessed in terms of its rhythmic qualities. Formalists argue that words in poetry are combined in such a way that they violate syntactic constructions. As we find it in ordinary speech. Poetic syntax differentiates itself from that of ordinary language. The poetic sentences are explained in terms of their effect on the laws of rhythm.

A full understanding of poetry needs that both the phonic and syntactic structures be analysed according to the laws of poetry without taking account of those of ordinary language that overlook the verbal nature of poetry and transforms it from the domain of language to that of music (Jefferson and Robey, 1986:38). An analysis of poetry should be concerned with the technique which makes it different from ordinary speech. The third level deals with its semantic principle. Poetic language differs from ordinary language in semantic content. Words are used in ordinary language in order to communicate a specific idea, while in poetry, words activate a secondary meaning, thus creating ambiguity. Each level of poetic analysis focuses on the defamiliarizing capacity of the poem: image, hyperbole, personification, comparison, repetition or any other trope and potentially all qualify effective communicating poetic violence on ordinary language. (Jefferson and Robey 1986:38-39). 
Personification attributing human characteristics to non-human objects or ideas.

Scheffler (2015:171) asserts the following on personification:

A figure of speech in which inanimate abstract and non-human things are given human attributes. It is used extremely in poetry to describe and express mood, thought and emotion.

Hees and Lawton (1979:63) state as follows:

Personification is a kind of image too. It is a kind of image where something concrete relates to human beings while something else is not human.

The object in personification can be addressed as if it is a human being, or be made to speak. In so doing, the poet makes the reader identify himself with the object so that the feeling expressed by the object has immediate and direct appeal to him.

Cuddon (1980:501) views personification as:

The impersonification or embodiment of some quality or abstraction; the attribution of human quality to inanimate objects.

Imagery is manifested in personification. It can be the concretive, animistic or anthropomorphic metaphors. These three categories reflect the tendency of metaphors to elucidate the undifferentiated areas of human experience.

The poem, Isahara is endowed with human attributes. It is a desert which is geographically situated in the northern part of the African continent. It is an anthropomorphic metaphor. The Sahara desert is inanimate, but the poetic attributes of animate characteristics are endowed to it when he remarks:
Deda Sahara uyonats' elwandle,
Deda uyodl' elwandle.
(Shongwe 1985:4)
(Get out to drink at the sea, Sahara,
Get out to eat at the sea.

In poetry, we grasp the nature of an inanimate object more vividly by breathing life into it. Nature becomes real when there are projections into the identified qualities of the object. It appears the Sahara desert is expected to respond to the instruction:

$$
\begin{aligned}
& \text { Sahara ngiphendvule... } \\
& \text { (Shongwe 1985:4) } \\
& \text { Sahara, give a me a reply... }
\end{aligned}
$$

The poet attributes the animal qualities to the Sahara desert:

$$
\begin{aligned}
& \text { Deda, deda simiti.... } \\
& \text { (Shongwe 1985:4) } \\
& \text { (Simiti, move aside). }
\end{aligned}
$$

The desert is taken as a swallower. It appears to be a big animal that is disturbing the continent. The poet condemns the occurrence of this desert. Its presence promotes famine, poverty and socio-economic instability. The animate properties are ascribed to an inanimate natural phenomenon.

Shongwe, in his poem, Sahara attacks the social injustice brought in this country by apartheid. He calls 'Sahara' to be dismantled so that peace and prosperity in the country can prevail. He sees this Sahara as an oppressor. The metaphoric nature of the Sahara Desert to Apartheid, amongst the others, is the dryness of the desert, the feeling of uncertainty, lifelessness as well as hunger. His dream came true when apartheid was buried on $27^{\text {th }}$ April 1994.

Sahara Desert (iSahara) is an allegorical poem, which is composed of the largest desert in Africa. The desert extends from the Atlantic on the west. On the Northwest, the atlas mountains provide a precise boundary. On the South, it merges into a trader's steppe region. It stretches through the Niger valley, Lake Chad and eastward into Sudan. The desert is endowed with animal attributes when the poet remarks that it crawls like a cat species with dignity and respect. Although it is respectable, it imposes poverty and famine. The remarkable word, sitfunti (moral weight) influences prestige and endorse human attributes. The animal attributes are evident in the following lines: 


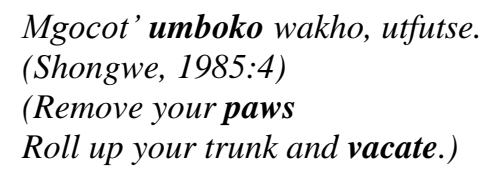

There are two animals that are implied, the lion and the elephant. The paws are associated with the lion, the wild, the most feared, king of beasts and carnivores animal. The trunk is for an elephant, a strict vegetarian and overeating animal. The desert, Sahara is endowed with various animals attributes in the poem. It is further noted that the desert, Sahara is associated with powerful and feared animals.

Its negative impact in Africa is felt due to landforms that are rocky, called hamada and gravelly called reg. plant life is very meagre. Few species of animals are found clustered in the areas with greater availability of water, the oases and the steppes. The diction that is used by the poet expresses the desert asumcindzeteli (an oppressor), the powerful and most feared animals, libhubesi (lion) and indlovu (elephant). The central idea of a poem is an expression of dissatisfactory and protest against poor socio-economic conditions and unhealthy socio-political situations.

The poem, Lembe unguShaka is remarkable in the sense that the poet personifies the native hoe. The poet employs an inanimate cultural phenomenon lilembe to call King Shaka. He uses an anthropomorphic or humanizing metaphor to put forth his ideas. A native hoe is given human characteristics. Shongwe revives the impact that Shaka had in Southern Africa. King Shaka's bravery, power, wisdom spread world-wide. He figuratively presents King Shaka's impacts:

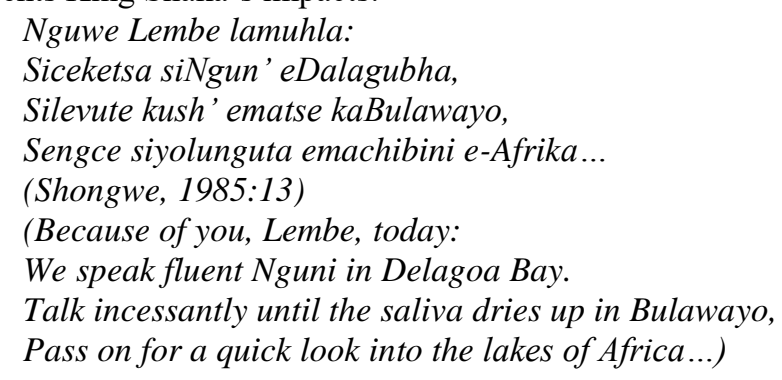

He figuratively calls King Shaka the native hoe. He ascribes the human qualities to hoe. He uses synecdoche for further attribution of human qualities and elucidation of historical events. Through the native hoe, the people are bold and loquacious in different countries. Hawkes (1972:4) defines synecdoche as:

A Greek word derives from synekdechesthai meaning to receive jointly. The transference takes the form of part of something being carried over to stand in a place of the whole thing, or vice versa.

The human characteristics that are transferred to the native hoe in different geographical areas lead to synecdoche. The word, eDalagubha which is an adverb of place, stands in a place of the whole country, Mozambique. The word, kaBulawayo and Emachibini e-Afrika stand in a place of Zimbabwe and from Zambezi River to central Africa respectively. On the other hand, the poet ascribes the inanimate properties to him.

He uses depersonification which is the technique characterised by giving a person the non-personal characteristics. The further explanation highlights that all the South African's nations are longing for the new Shaka: a hero who will unite all the nations irrespective of their different philosophies of life, their ethnicity, their creed and their colour.

\section{Human features}

In some poems studied, the poets give animals and inanimate beings physical characteristics that are found in human beings. This personifies non-human features. The poem, Umfula Inkomazi (The Inkomazi River) has this characteristic as shown in the excerpt that follows:

Hamba nkhosikati lemabelekati.

(Shongwe, 1985:10)

(Go, queen with big udder).

The word, emabele has different meaning in Siswati language. It means sorghum millet or udder (teat) through which human baby sucks milk. Human beings have emabele, whilst animals have imibele. There is, however, no distinction between the two words in English. Shongwe chooses to use emabele for a woman to personify the Inkomazi River. It is known that a river has no teats. He is telling his reader that this river is a caring woman 
who is able to stand for the maintenance of her children's, which the Inkomazi River does by providing water to physical and human phenomena.

In his poem entitled, Inkomazi (Nkomazi River), he has been able to use personification. He says, nkhosikati (woman) referring to a river. This woman is able to breastfeed her babies. He even says that she (this river) has big breasts. Human beings and animals are able to breastfeed not inhuman things like a river. In this poem: Hamba (walk) is as if the river is a person who can walk. A river cannot walk but can flow.

In the same poem, the poet is emphasising that he has seen the river feeding all people hence he calls these people that they are its children that is why he says in his poem:

Uhamb' umunyisa bantfwabakho,

(Shongwe, 1985:10)

(As you flow to feed your children.)

The poet in the same poem is begging the Nkomazi River to flow very fast in order to feed the people by its endless milk as he says:

Shakutela njalo Nkomazi.

Umunyise ngelubisi lwakho lolungapheli.

(Shongwe, 1985:10)

(Flow very fast Nkomazi.

Feed them with your endless milk)

The poet is asking the river to flow and feed all the nations without discriminating hence he says:

Gijima njalo Nkomazi,

Uphakele unganalubandlululo.

(Shongwe, 1985:10)

(Keeps on flowing Nkomazi River,

Feed them without discrimination.)

\section{Human emotions}

In this poem, Lelijaha (This young man), the following human emotions are used:

Siyawubonga umusa wakho,

Siyalubonga lutsandvo lwakho.

(Luphoko, 1985:29)

(We thank you for your kindness,

We thank you for your love.)

Luphoko personifies a bus by giving it human emotions, kindness and love. In this case, an inanimate object, the bus is personified as a very kind and loving person. Only human beings can be kind and loving.

In conclusion on personification, it is noted that most inanimate objects and concept like, Sahara desert, Lilembe (native hoe) and Inkomazi River are endowed with human attributes. It is a device that ascribes the characteristics of humans to inanimate objects by implication rather than by explicit statement.

\section{Imagery manifested in hyperbole}

A hyperbole is a figure of speech that exaggerates extremely or excessively with the aim of emphasizing the point. Hyperbole can be exaggerated beyond the natural boundary and it can sometimes misinterpret the truth.

Reaske (1966:34) states as follows:

A figure of speech which employs exaggeration ...it is extremely or excessive ...hyperbole can produce a very dramatic effect...

Myers and Simms (1989:136) concur with Reaske when they define hyperbole as follows:

A rhetorical form of comparison, which uses exaggeration or obvious overstatement for comic or dramatic effect the opposite term is litotes, a form of understatement used ironically.

Cuddon (1980:316) defines hyperbole as:

A figure of speech which contains an exaggeration for emphasis. It is used by poets to emphasize a feeling or to produce a humorous effect, that is, to bring it to the listener to understand how great, how enormous, how extra-ordinary the concept described is. 
According to Abrams (1988:86), hyperbole is defined as:

A figure of speech which is bold overstatement or extravagant exaggeration of act or of possibility, used either for serious or ironic effect.

Exaggeration is another technique of defamiliarisation and incredible because of variance with the day-to-day standard of language. In poetry for an example, hyperbole distorts by overstating.

Fowler (1980:167) defines hyperbole as follows:

The use of exaggerated terms for the sake of deception, but for emphasis.

Orwell (2005:119) sees hyperbole as follows:

Deliberate exaggeration, for example, to describe something in such a way that it seem much bigger than it really is.

Hyperbole is a figure of speech which is contrary to the litotes. It is the figure of overstatement while litotes is an understatement. It misrepresents the truth. It sometimes distorts the truth. In the poem, Libhubesi (The lion), the poet says:

\author{
Ubhodla kunyakat me tintsaba \\ Kusiphuke tinwele tebafelokati.... \\ (Shongwe, 1985:22) \\ (You roar that the mountains shake \\ And the hair of the poor destitute man uprooted...)
}

The whole action is exaggerated. Hyperbole belies the state of affairs we actually understand to exist either in the real world or imaginary world created by the poet. It distorts the roaring of the lion. The whole extract features an overstatement. It makes us question the notion of the truth and falsehood in literature. It scratches almost to the breaking point of the communication of resources. Sometimes, it oversteps the bounds of acceptability. Simply, the poet says that when the lion roars, an anchor sound is heard and the poor destitute man is scared.

The poet leads to a more profound kind of the truth which eludes factual statement. We no longer expect a poet to tell the truth in the same sense as the historian. Hyperbole mainly evaluates meaning. It serves to colour the expression of personal feelings and opinions.

Unyatsela kulilitele tinyoni...

(Shongwe, 1985:22)

(You trample and the birds ululate shrill cries of pleasure)

The trampling of the lion is exaggerated. The statement is incredible in the given situation because it is outside the bounds of possibility. The idea of the shrill cry of the birds is the subjective claim of the poet that we could not verify. It appears the birds are positively admiring the trampling of the lion.

The whole poem is full of exaggerations. The poet admires the appearance, behaviour and the life of the lion. He manipulates all the lion's characteristics using his subjective feelings. In the first extract, he links the lion with the mountains that are given human behaviour. In the second extract, he links the lion with the birds that are attributed to human qualities.

Shongwe in his poem entitledPhumula Langa(Let the sun rest), is telling people that it is sunset. The sun must rest because it was providing light to the people all day long. Now that the sun has set, stars have taken their duty to keep on providing the light to the people during the night. He says:

$$
\begin{aligned}
& \text { Seliyombats' ingubo lilanga } \\
& \text { Yingako sekudlala tinkhanyeti. } \\
& \text { (Shongwe, 1985:14) } \\
& \text { (It is towards sunset } \\
& \text { That is why stars are shining) }
\end{aligned}
$$

The poet is exaggerating when he says stars are visiting each other and play with the mirrors and light to one another. Moving up and down in this stanza he has managed to use exaggeration because stars cannot use tails since they do not have such. In the following line, Shongwe (1985:14) explicitly emphasises his statement when he says:

$$
\text { Uyotibukela setintjikitis' imisidlana. }
$$


(You will see them waving their tails)

Now that is dark, gangsters are coming to disrupt society. Hyperbole is found in the following example:

Selembets' ingubo lilanga

(Shongwe, 1985:14)

(A blanket covers the sun)

In the poem, the poet is figuratively telling us that it is dark. Owls are singing badly. The poet supports his statement by saying:

\author{
Nato netahhukulu setibhimba. \\ (Shongwe, 1985:14) \\ (There are owls singing in discord.)
}

The singing of the owls is extremely expressed as opposed to the combined effect of rhyme, rhythm and melodious sounding voices that produced the musical cadences. Having examined hyperbole, it is evident that a deliberate statement of facts is emphasized. There are various phases that depict exaggeration and extension of meanings for a poetic flavour. The poetic diction and phrases that are used in all selected poems are reflecting hyperbole. It is the communicative resources of language that can overstep the boundaries of acceptability.

\title{
Conclusion
}

The poems that are selected for this exploratory study are the following: Sahara (Sahara Desert), Lembe UnguShaka (Native Hoe), you are King Shaka), Umfula Inkomazi (Inkomazi River), Lelijaha (This Young Man), Libhubesi (The Lion) and Phumula Langa (Let the sun rest)) the use of figure of speech contributed to the vividness of expressions and themes of the poems. Both rhetoric devices compare and associate the concepts by heightening theme and emphasizing the effects. It is the study that is guided by Formalism approach based on poetic sounds, syntactic and semantic constructions. They are used to achieve a special meaning or effect in all modes of discourse. They are integral to the functioning of language in a connotative manner.

\section{Recommendation}

Having explored personification and hyperbole in various Siswati poems, the researcher concludes that more workshops on poetry skills and techniques to writers are needed. Further classification of each figure of speech according to animate, inanimate, structural and thematic observations is warranted.

\section{References}

[1]. Abrams, M.H. 1988. A Glossary of Literary Terms. New York: Rinehart and Weston.

[2]. Cuddon, J.A. 1980. A Dictionary of Literary Terms. London: McGraw Hill.

[3]. Cohen, B.B. 1973. Writing About Literature (revised edition). New York: Scott Foresman and Co.

[4]. Fowler, R. 1987. A Dictionary of Literary Terms. London: Rutledge \& Kegan Paul.

[5]. Jefferson, A, and Robey, D.1986. Morden Literary Theory: A Comparative Introduction. London: BT Batsford.

[6]. Scheffler, B. 2015.Vistas of Poetry. Alberton: Lectio Publishers.

[7]. Heese, M, and Lawton, R. 1979. The New Owl Critic. An Introduction to Literary Criticism. Goodwood: National Books Printers.

[8]. Orwell, G. 2005.Animal Farm. London: Penguin Publishers.

[9]. Shongwe, J.P. 1985. Sihlenge Setinkondlo. Pietermaritzburg: Shuter and Shooter (Pty) Ltd.

[10].Heese, M, and Lawton, R. 1970. The Owl Critic. Elsies River: Nasou Publishers.

[11].Hawkes, T. 1972. Structuralism and Semiotic. London: Methuen.

[12].Luphoko, J.P. 1984.Asikhutulisane. Pretoria: De Jager Haum Publishers.

[13].Reaske, C.R. 1966. How to Analyse Poetry. New York: Monarch Press

[14].Myers, J, and Simms, M. 1989. The Longman Dictionary. New York: Longman, Inc.

[15].Van Staden, P.T. 1980. Beelspraak in Sefalana saManate. Potchefstroom: PU for CHE (Thesis-Ph.D) 